\title{
Bactericidal activity of the sera of rabbits immunized with Vibrio cholerae O1 whole cell extract
}

\author{
Tasmina Rahman ${ }^{1 \ddagger}$ and Chowdhury Rafiqul Ahsan ${ }^{2}$ \\ ${ }^{1}$ Department of Microbiology, Stamford University Bangladesh, 51 Siddeswari Road, Dhaka-1217, Bangladesh; ${ }^{2}$ Department of \\ Microbiology, University of Dhaka, Dhaka-1000, Bangladesh
}

Received 12 February 2012/Accepted 21 April 2012

\begin{abstract}
Vibrio cholerae serotype $\mathrm{O1}$ causes diarrhea in many developing countries around the world. In most cases, cholera patients pose some sorts of immunity against the naturally occurring infection. In the present study, the bactericidal activity of the sera of rabbit immunized with whole cell extract of Vibrio cholerae $\mathrm{O1}$ was investigated. The protein profile of the serotype exhibited 20 types of proteins of distinguished molecular weights. The western blot analysis revealed at least 10 proteins to be immunogenic. Interestingly, decomplementation of the sera was found to abolish the bactericidal activity. The bactericidal activity of non immunized rabbit sera was also investigated and the results revealed that the immunized sera were more effective than that of non immunized one.
\end{abstract}

Key words: Vibrio cholerae O1; rabbit sera; bactericidal activity

Cholera is an acute, diarrheal illness caused by the infection of the intestine with the bacterium Vibrio cholerae. Serological classification of $V$. cholerae was first described by Gardner \& Venkatraman in 1935 (1), on the basis of differences in the sugar composition of the heat-stable surface somatic "O" antigen. Currently the organism is classified into 206 "O" serogroups $(2$, 3).

Cholera is usually characterized as a life-threatening secretory diarrhea induced by cholera enterotoxin (CT), secreted by virulent type of $V$. cholerae. Subsequent purification and structural analysis of the toxin showed the toxin consist of an A subunit and 5 smaller identical B subunits (4). The A subunit possesses a specific enzymatic function and acts intracellularly, raising the cellular level of cAMP and thereby changing the net absorptive tendency of the small intestine to one of net secretion. The B subunit helps the toxin to bind the eukaryotic cell receptor, ganglioside GM1. The binding of CT to epithelial cells is enhanced by neuraminidase. Apart from the obvious significance of CT in cholera pathogenesis, it is now clear that the production of CT by $V$. cholerae is important from the perspective of a serogroup having the potential to cause epidemics (5). This has become particularly evident since the emergence of $V$. cholerae $\mathrm{O} 139$. A dynamic $4.5 \mathrm{~kb}$ core region, termed the virulence cassette (6), has been identified in toxigenic V. cholerae $\mathrm{O} 1$ and $\mathrm{O} 139$ but is not found in non-toxigenic strains.

Although both $V$. cholerae $\mathrm{O} 1$ and $\mathrm{O} 139$ elaborate

${ }^{\ddagger}$ Corresponding author. Mailing address: Tasmina Rahman, Department of Microbiology, Stamford University Bangladesh, 51, Siddeswari Road, Dhaka1217; Email: tasmina_mb@yahoo.com. similar cholera toxin (7), they differ in the composition of their surface components as $V$. cholerae $\mathrm{O} 139$ produces a polysaccharide capsule (8). Thus previous exposure to $V$. cholerae $\mathrm{O} 1$ does not confer immunity against $V$. cholerae O139 (5, 9, 10). Antibodies against various cholera antigens such as lipopolysaccharides (LPS), outer membrane proteins, cholera toxin and toxin-coregulated pilus (TCP) have been detected in sera from individuals immunized with $V$. cholerae $\mathrm{O} 1$ or from convalescent patients (11-15).

A thorough study of immune responses against various somatic antigens is possible in experimental animals such as rabbits $(16,17)$. Although cholera is a toxin-mediated disease, the predominant protective immune mechanism appears to be antibacterial rather than antitoxic (18). While the role of LPS in protective immunity has been indicated from a field trial in Bangladesh (19), the contribution of other components of $V$. cholerae $\mathrm{O} 1$ in protection has not been definitely identified. A study from Bangladesh on cholera reinfection noted that clinical infection due to $V$. cholerae $\mathrm{O} 1$ of classical biotype conferred complete protection for 3.5 years against subsequent cholera due to either biotype (20). However, an initial infection with El Tor did not offer protection against subsequent cholera due to the heterologous classical biotype and offered poor protection (29\%) against homologous El Tor cholera infection.

New oral cholera vaccines promise substantial protection without side effects. A killed oral vaccine (Dukoral) consists of killed V. cholerae organisms along with the cholera $\mathrm{B}$ subunit, and the vaccine therefore stimulates both antibacterial and antitoxic immunity. Two doses are given 1-6 weeks apart (21). The other vaccine (Orochol) is an avirulent mutant of $V$. cholerae; strain 
CVD103HgR, given as a single-dose, lyophilized oral vaccine (22).

The present study was, therefore, undertaken to examine the susceptibility of $V$. cholerae $\mathrm{O} 1$ to immunized and non immunized rabbit sera along with the demonstration of the antigenic profile of the organism.

\section{MATERIALS AND METHODS}

Bacterial strain. $V$. cholerae serotype $\mathrm{O} 1$ was obtained from the Department of Microbiology, University of Dhaka, Bangladesh. The strain was identified by Gram staining, and by observing the typical phenotype (yellow colonies) on Thiosulphate Citrate Bile Salt Sucrose (TCBS) agar.

Preparation of sonicated whole cell extract. The strain was grown in Brain Heart Infusion Broth (BHIB) and cells were harvested by centrifuging the culture at $8000 \mathrm{rpm}$ for 10 minutes. The cells were then subjected to sonication. Cell suspension in distilled water was placed in an ice cool chamber and was sonicated by ultrasonic vibration ( $30 \mathrm{sec} \times 8$ time). Sonicates were then centrifuged at $12000 \mathrm{rpm}$ for $10 \mathrm{~min}$ at $10{ }^{\circ} \mathrm{C}$. The supernatant was then stored at $-20^{\circ} \mathrm{C}$ by alliquoting in Eppendorf tubes.

Collection of healthy rabbit sera. Blood from healthy non immunized rabbits were collected from ear vein puncture at day 0 and stored at $-20{ }^{\circ} \mathrm{C}$ until used.

Immunization of rabbits. Two New Zealand white rabbits (1.5-2.0 kg body weight) were immunized with the sonicated whole cell extract of $V$. cholerae by the doses listed in Table 1. Within 7 days of the final dose administration, antibody development was confirmed by slide agglutination test (23). Sera were separated and were stored at $-20{ }^{\circ} \mathrm{C}$.

TABLE 1. Doses of immunization of Rabbits

\begin{tabular}{cccc}
\hline Doses & $\begin{array}{c}\text { Concentration } \\
(\mu \mathrm{g} / \mathrm{kg} \text { body } \\
\text { weight })\end{array}$ & Route & Diluent \\
\hline 1 & 50 & IM & Incomplete adjuvant \\
2 & 50 & IM & Complete adjuvant \\
3 & 30 & IV & Saline \\
4 & 30 & IV & Saline \\
5 & 30 & IV & Saline \\
\hline
\end{tabular}

$\mathrm{IM}=$ Intra-muscular; IV = Intra-vascular

SDS-PAGE analysis. To determine the protein profile of the different proteins in the whole cell extract of the $V$. cholerae $\mathrm{O} 1$, the cell extract were subjected to SDS-PAGE analysis (24). A $10 \%$ separating gel was constructed by gently mixing the distilled water, lower gel buffer along with $10 \%$ SDS and acrylamide bis acrylamide solution followed by rapid addition of the $10 \%$ freshly prepared Ammonium per Sulfate (APS) and TEMED. The solution was dispensed in a gel casting unit and allowed to stand for 2 hours for polymerization. Stacking gel mixture was also prepared by primarily mixing the distilled water, upper gel buffer along with 10\% SDS and acrylamide bis acrylamide solution followed by addition of $10 \%$ APS and TEMED. The gel mixture was then rapidly poured above the previously constructed separating gel. The protein sample was mixed with sample loading buffer at a ratio of $1: 1$ and was then boiled in water bath for 2-3 minutes. $5 \mu$ l tracking dye $(0.1 \%$ Bromophenol blue) was then added to the boiled mixture. $25 \mu \mathrm{l}$ of sample was then added to four wells. The first column from left was loaded with $5 \mu \mathrm{l}$ of molecular weight standard (Invitrogen, Mark $12^{\mathrm{TM}}$ Standard, Catalog no. LC5677). Electrophoresis was performed at $10 \mathrm{~mA}$ for 2-2.5 hours. Finally, the gel was stained with fresh staining solution $(0.1 \%$ Coommassie Brilliant blue R250) for 2 hours.

Western blot analysis. Western blot technique was applied to check the immunological response of the pre-immunized polyclonal rabbit serum against the antigens from whole cell extract of $V$. cholerae $\mathrm{O} 1$ (25). The protein bands separated by SDS-PAGE were transferred to nitrocellulose membrane by keeping the casting sandwich at 10 volt for overnight. The whole paper was cut into 4 strips, labeled $\mathrm{m}, \mathrm{c}, \mathrm{R}_{1}, \mathrm{R}_{2} . \mathrm{c}, \mathrm{R}_{1}, \mathrm{R}_{2}$ were transferred to a plastic box and was incubated for at least 1 hour in $2 \%$ skim milk on a rotary shaker. Strip labeled $\mathrm{m}$ was kept undisturbed for the calibration of the molecular weight of the proteins that are immunogenic. $200 \mu$ of the three different rabbit serum (c, $\mathrm{R}_{1}, \mathrm{R}_{2}$ ) was taken in three falcon tubes containing $5 \mathrm{ml}$ of $2 \%$ skim milk, thus providing primary antibody in a concentration of 1:25 dilution and were shaken at room temperature on a rotary shaker for 1.5 hour. The protein bands were labeled by soaking in a solution of secondary antibody (Alkaline phosphatase conjugated goat antirabbit antibody, whole molecule; Sigma, USA) diluted at 1:5000 in 2\% skim milk and was shaken for 1 hour.

Molecular weight determination. To determine the relative mobility $\left(\mathrm{R}_{\mathrm{f}}\right)$ of the protein, migration distance of the protein was divided by the migration distance of the tracking dye.

$$
\text { Relative mobility }\left(\mathrm{R}_{\mathrm{f}}\right)=\frac{\text { Distance of protein migration }}{\text { Distance of the tracking dye migration }}
$$

A calibration curve was prepared by using the molecular weight standards (Kaleidoscope prestained standards, Catalog No: 161-0324, Control 94501, BioRad, USA).

Serum bactericidal killing. The bactericidal activity of the hyper immune rabbit sera was compared with that of non-immunized rabbit sera (26). The strain was cultured on Luria Bertani agar at $37^{\circ} \mathrm{C}$ for 24 hours. Strain suspension of about 5.5 $\log _{10} \mathrm{cfu} / \mathrm{ml}$ were treated with sera (immunized and non immunized) in normal saline and incubated at $37^{\circ} \mathrm{C}$ for one hour.

Treatment of sera. Both the immune and non immune rabbit sera were decomplemented by heating at $56{ }^{\circ} \mathrm{C}$ for 30 minutes (27). After all the treatments, the sera were subjected to serum bactericidal assay. Serum without any treatment was used for the control bacterial suspension.

\section{RESULTS AND DISCUSSION}

A significant characteristic of natural host defense mechanism against Gram negative bacteria is the bactericidal activity of serum (26). Exposure of many strains of Gram negative bacteria against suitable concentration of human or animal serum results in the loss of viability and sometimes causes dissolution of the bacterial cells. The mechanism of this specific immunity is a combination of the complement dependent bacteriolylic and the opsonic activities of antibody (28). In the present study, the sera of rabbits immunized with $V$. cholerae $\mathrm{O} 1$ was tested for the bactericidal activity. Therefore, SDS-PAGE and Western blot analysis was performed to determine the performance of immunization of the rabbits.

Separation of protein bands and determination of immunogenic proteins. Twenty proteins were detected after electrophoretic separation of the antisera (Fig. 1). Western blot analysis was performed To detect the proteins that were antigenic. Ten proteins were shown to be immunogenic from which 5 proteins were prominent in the immunogenic reaction while the others were less immunogenic. All the immunized rabbit sera $R_{1}, R_{2}$ presented the same sort of immunogenic reaction, that is, they gave same antigenic bands (Fig. 2). Molecular weight of the protein bands was determined from the standard curve (Table 2). The present investigation revealed that the antisera raised against the whole cell extract of $V$. cholerae $\mathrm{O} 1$ consisted of some proteins in relatively high concentrations, which imparted immunogenic effect on patients (Fig. 1 and 2).

Bactericidal activity of serum. The bactericidal activity of the immunized sera was observed to be more effective than that of the non-immunized sera. The complement mediated activity was also determined by comparing the effect of heated sera (Fig. 3). The complement mediated antibacterial activity was only 
found in the non-heated serum sample.

Furthermore, when the bactericidal activity of the rabbit sera was examined against $V$. cholerae $\mathrm{O} 1$, it was observed that the strain tested was highly susceptible to serum mediated killing. The bactericidal effects of nonimmune sera are mediated by activated components of classical or alternative pathway of complement and activation of either can lead to membrane damage culminating in cell death.

\section{Lane: 1}

Lane: 2

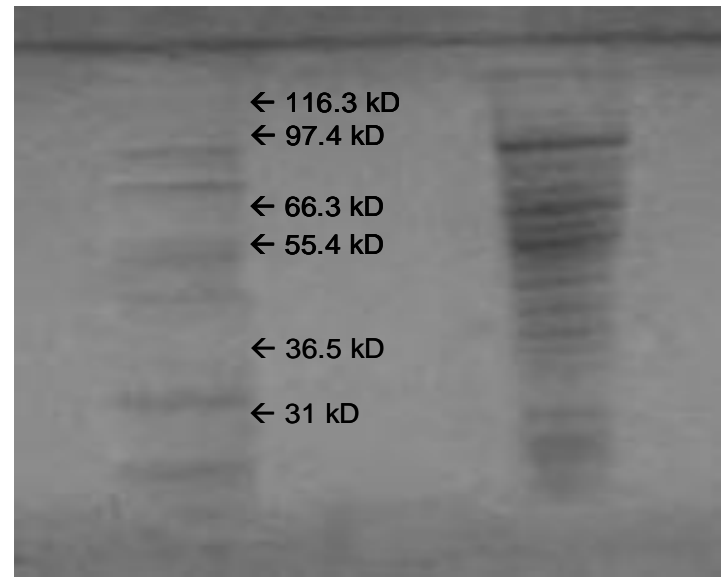

FIG. 1. SDS PAGE analysis for the antiserum raised against the whole cell extract of $V$. cholerae $\mathrm{O} 1$. About 20 proteins were found to appear after electrophoresis. Immunogenic protein bands were determined by western blot assay. Lane 1: Molecular weight marker; Lane 2: Sample.

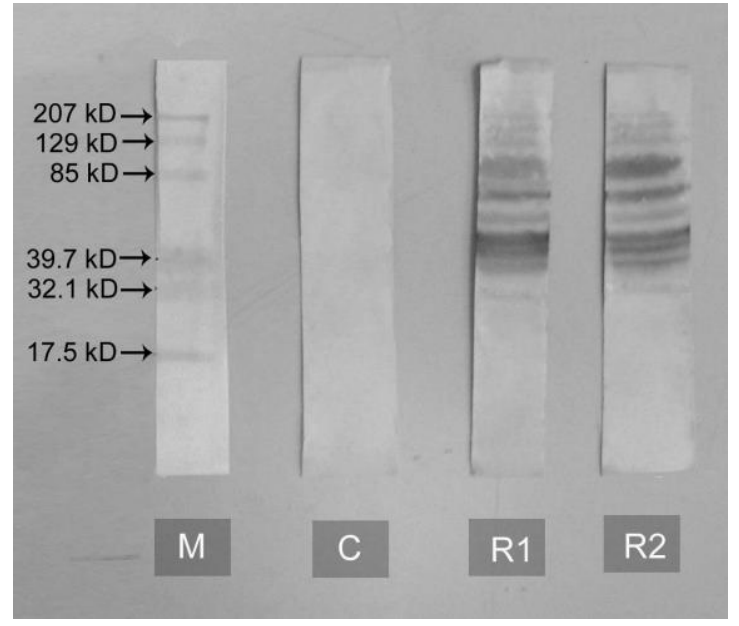

FIG. 2. Western blot analysis of antiserum raised against the $V$. cholerae 01. 5 proteins were found to be more immunogenic among 10 protein bands. $\mathrm{M}=$ molecular weight marker; $\mathrm{C}=$ control; $\mathrm{R} 1=$ rabbit $1 ; \mathrm{R} 2$ = rabbit 2 .

\section{CONCLUSION}

The present study revealed that both the classical and alternative pathways were involved in the serum
TABLE 2. Relative mobility of the proteins those are immunogenic against the rabbit serum $1\left(\mathrm{R}_{1}\right)^{*} \&$ Rabbit serum $2\left(\mathrm{R}_{2}\right)^{*}$ and the corresponding molecular weight.

\begin{tabular}{ccc}
\hline $\begin{array}{c}\text { Protein (top to } \\
\text { bottom) }\end{array}$ & $\begin{array}{c}\text { Relative mobility } \\
\left(\mathrm{R}_{\mathrm{f}}\right)\end{array}$ & $\begin{array}{c}\text { Molecular weight } \\
(\mathrm{kD})\end{array}$ \\
\hline Band 1 & 0.14 & 147 \\
Band 2 & 0.16 & 137 \\
Band 3 & 0.2 & 122 \\
Band 4 & 0.26 & 104 \\
Band 5 & 0.32 & 89 \\
Band 6 & 0.38 & 77 \\
Band 7 & 0.42 & 70 \\
Band 8 & 0.46 & 64 \\
Band 9 & 0.49 & 59 \\
Band10 & 0.57 & 49 \\
\hline
\end{tabular}

*Each rabbit serum exhibited same pattern of bands

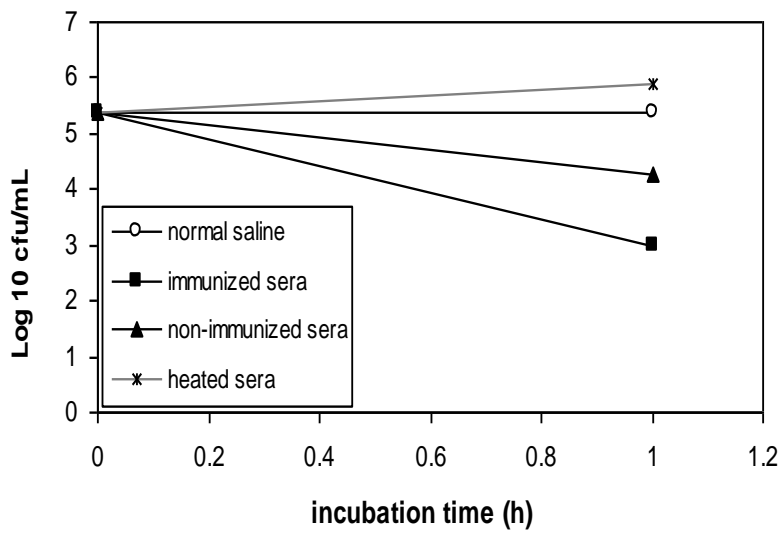

FIG. 3. Determination of the bactericidal activity of immunized and non immunized rabbit sera. Heated serum sample showed no antimicrobial activity, whereas non heated serum sample retained the antimicrobial activity. Moreover, immunized serum was more bactericidal than that of non immunized one.

mediated killing. Inactivation of both the classical and alternative pathway by heating the sera at $56{ }^{\circ} \mathrm{C}$ for 30 minutes completely abolished the serum bactericidal activity which further supports that the serum bactericidal activity against $V$. cholerae $\mathrm{O} 1$ strain is mediated by both classical and alternative pathways.

\section{REFERENCES}

1. Gardner, A. D. and K. V. Venkatraman. 1935. The antigens of the cholera group of vibrios. Journal of Hygiene, 35: 262-282.

2. Shimada, T. E. et al. 1994. Extended serotyping scheme for Vibrio cholerae. Current Microbiology, 28: 175-178.

3. Yamai, S. et al. 1997. Distribution of serogroups of Vibrio cholerae non-O1 non- O139 with specific reference to their ability to produce cholera toxin and addition of novel serogroups. Journal of the Japanese Association for Infectious Diseases, 71: 1037-1045.

4. Finkelstein, R. A. and J. J. Lospalluto. 1969. Pathogenesis of experimental 
experimental cholera: preparation and isolation of choleragen and choleragenoid. Journal of Experimental Medicine 130: 185-202.

5. Albert, M. J., et al. 1993. Large outbreak of clinical cholera due to $V$. cholerae non-O1 in Bangladesh. Lancet 341: 704.

6. Trucksis, M. et al. 1993. Accessory cholera enterotoxin (Ace), the third toxin of a $V$. cholerae virulence cassette. Proceedings of the National Academy of Sciences, 90: 5267-5271.

7. Hall, R. H., et al. 1994. Vibrio cholerae non-Ol serogroup associated with cholera gravis genetically and physiologically resembles $01 \mathrm{El}$ Tor cholera strains. Infect lmmun 62: 3859-3863.

8. Johnson, J. A., et al. 1994. Vibrio cholerae O139 synonym bengal is closely related to Vibrio cholerae El Tor but has important differences. Infect. Immun. 62: 2108-2110.

9. Mahalanabis, D., et al. 1994. An epidemic of cholera due to Vibrio cholerae $\mathrm{O} 139$ in Dhaka, Bangladesh: Clinical and epidemiological features. Epidemiol Infect 112: 463-471.

10. Bhattacharya, S. K., et al. 1994. Epidemic of Vibrio cholerae O139 in Calcutta. Indian J Med Res 100: 213-216.

11. Majumdar, A. S., P. Dutta, D. Dutta, and A. C. Ghose. 1981 Antibacterial and antitoxin responses in the serum and milk of cholera patients. Infect lmmun 32: 1-8.

12. Kabir, S. 1983. Immunochemical properties of the major outer membrane protein of Vibrio cholerae. Infect lmmun 39: 452-455.

13. Black, R. E., et al. 1987. Protective efficacy in humans of killed wholevibrio oral cholera vaccine with and without the B subunit of cholera toxin Infect Immun 55: 1116- 1120.

14. Richardson, K., J. B. Kaper, and M. M. Levine. 1989. Human immune response to Vibrio cholerae $\mathrm{Ol}$ whole cells and isolated outer membrane antigens. Infect lmmun 57: 495-501.

15. Asaduzzaman, M., et al. 2004. The major subunit of the toxincoregulated pilus TcpA induces mucosal and systemic immunbglobulin A immune responses in patients with cholera caused by Vibrio cholerae $\mathrm{O} 1$ and O139. lnfect lmmun 72: 4448- 4454.

16. Kabir, S. 1987. Immunological responses of rabbits to various somatic and secreted antigens of Vibrio cholerae after intra-duodenal inoculation. J Med Microbiol 24: 29-40.
17. Guinee, P. A., et al. 1987. Protective immunity against Vibrio cholerae infection in the rabbit. Zentralbl Bakteriol Mikrobiol Hyg [A] 266: 552-562.

18. Levine, M. M., et al. 1979. lmmunity of cholera in man: relative role of antibacterial versus antitoxic immunity. Trans R Soc Trop Med Hyg 73: 3-9.

19. Mosley, W. H., et al. 1973. Field trials of monovalent Ogawa and lnaba cholera vaccines in rural Bangladesh: three years of observation. Bull World Health Org 49: 381-387.

20. Clemens, J. D., et al. 1991. Biotype as determinant of natural immunizing effect of cholera. Lancet 337: 883-884.

21. Holmgren, J., J. Clemens, D. A. Sack, and A. M. Svennerholm. 1989. New cholera vaccines. Vaccine 7: 94-96.

22. Tacket, C. O., et al. 1999. Randomized, double blind, placebo-controlled, multicentered trial of the efficacy of a single dose of live oral cholera vaccine CVD $103-\mathrm{HgR}$ in preventing cholera following challenge with Vibrio cholerae $\mathrm{O} 1 \mathrm{El}$ Tor Inaba three months after vaccination. Infect. Immun 67 6341-6345.

23. Centers for Disease Control and Prevention. 1999. Isolation and Identification of Vibrio cholera serogroups O1 and O139, p. 49-50. In aboratory Methods for the Diagnosis of Epidemic Dysentery and Cholera. CDC, Atlanta, Georgia.

24. Laemmli, U. K. 1970. Cleavage of structural proteins during the assembly of the head of bacteriophage $\mathrm{T}_{4}$. Nature 227: 680-685.

25. Towbin, H., T. Stachelin, and J. Gordon. 1979. Electrophoretic transfer of proteins from polyacrylamide gels to nitrocellulose sheets: procedure and some applications. Proc. Natl. Acad. Sci. USA 76: 4350-4354.

26. Taylor, P. W., and H. P. Kroll. 1983. Killing of an encapsulated strain of Escherichia coli by human serum. Infect Immun 39: 122-131.

27. Ciurana, B., and J. M. Tomas. 1987. Role of lippopolysaccharide and complement in susceptibility of Klebsiella pneumoniae to nonimmune serum. Infect Immun 55: 2741-2746.

28. Wood, W. B. 1969. Human immunity to Pseudumonas aeruginosa: II Relationship between heat stable opsonins and type-specific lipopolysaccharide. J Infect Dis 126: 277-287. 